\title{
Biopsy of Pylorus
}

National Cancer Institute

\section{Source}

National Cancer Institute. Biopsy of Pylorus. NCI Thesaurus. Code C51584.

Removal of tissue from the pylorus for microscopic examination, using an endoscope. 